\title{
On Rights without Natural Law
}

\author{
IVO CERMAN
}

What is important for the historiography of human rights is that Dan Edelstein worked with early modern texts on legal theory and recognized that the real issue was the question of rights after the social contract. ${ }^{1}$ Most historians would just ask whether philosophers acknowledged human rights or not, but would not enquire about further conditions. Another good thing is that he appreciates the historical logic which induced early modern thinkers to prioritize the reform of existing laws over the invention of new rights. ${ }^{2}$ These are signs that this interpretation is based on inductive reasoning and not deduced from preconceived conclusions. The problem, then, is that the book does not look for historical legal solutions to the survival of rights within a legal system but satisfies itself with the notion of the preservation regime. ${ }^{3}$ This might be the impact of the metaphorical language which approaches rights as if they were a flowing river or a growing plant. ${ }^{4}$ It should be said that such metaphors are quite common in intellectual history, but they may hide lacunae in relevant knowledge by creating fictional connections. Even though this story is balanced with some contextual reconstructions, it may be misread as another version of skepticism which denies the significance of natural law for the formulation of ,universal human rights“. If we take „human rights“ as a legal instrument artificially made, and not as a good to be protected, then we also have to explain how this instrument was construed and I am afraid that this is not possible without early modern natural law.

\section{The formulation of universal human rights}

Even though the narrative starts with the conviction that the belief in natural rights for all humans was already common in the early sixteenth century, I would say that this is a rather premature conclusion. ${ }^{5}$ What medievalist research proved is that the Roman legal legacy had been transformed into a rights-centered culture. ${ }^{6}$ Yet, even though Anglophone historians today use the expression "natural rights" in their discussions of the Middle ages, the late medieval thinkers did not have the notion of equal and universal

1 Dan Edelstein, On the Spirit of Rights, Chicago 2019.

2 IвIDEm, p. 139.

3 It should be noted that Diethelm Klippel had discussed a similar set of questions about the preservation and transfer regimes in the 1970s. See Diethelm KLIPPEL, Politische Freiheit und Freiheitsrechte im deutschen Naturrecht des 18. Jahrbunderts, Paderborn 1976.

4 For example, we learn that something „flows“ (p. 30, 233) like a „tributary“ (p.196, 221), or "grows“ (p. 221, 223) like a plant, and rights are given a "genealogy“ (p. 1, 59).

5 D. Edelstein, On the Spirit, p. 2.

6 Brian Tierney, The Idea of Natural Rights, Atlanta 1997. 
human rights. They were only speaking about rights, not universal rights inherent in all humans. ${ }^{7}$ When they were speaking about jus naturae, they set the notion within a very general framework of law which exceeded human-made law. When Aquinas ${ }^{8}$ or the later Spanish theologians Luis de Molina and Francisco Suarez were speaking about law, they meant law in its general, unlimited significance in the Bible, in nature and in human society. ${ }^{9}$ They were blurring all these areas into one huge law. It took first of all narrowing the realm of law down to human-made law, and human-related law.

The exclusion of law related to beings above humans (angels) and below humans (animals) occurred in Catholic thought during the sixteenth and early seventeenth centuries and it was linked to advancing the late-scholastic conception of man as a rational being, capable of discovering law by means of his/her own reason. This was something the Protestant thinkers strictly rejected. ${ }^{10}$ It was only the generation of compromising thinkers around 1600, to which Grotius belonged, which managed to reject the pessimistic notion of corrupted humans, and embrace the Catholic notion of humans as reasonable beings, and natural law as "dictatum rectae rationis" discovered by human reason. ${ }^{11}$ This confidence in human reason was another key step, but it led to the paradoxical fact that natural law in mature authors such as Pufendorf, Wolff and others depended on human abilities. It depended on how much human reason is able to discover. ${ }^{12}$

The other option was the Protestant belief, advocated by Philipp Melanchthon, that natural law makes itself known to humans by some kind of divine voice, or the surviving notitiae divinae inside us. ${ }^{13}$ This was a corollary of the Lutheran understanding of

7 What these early texts denote as „human rights“ was often meant to mean „different from animal“. The notion "derechos bumanos" employed by theologians in the Valladolid disputation of 1550-51 was already meant to bridge denominational and racial differences between European Christians and American pagans.

8 Thomas Aquinas, Summa theologica, Prima secundae (at https://www.corpusthomisticum.org/iopera. html, accessed on 26/02/2020).

9 Luis de Molina, De justitita et jure, Cuenca-Venezia-Amberes 1593, vol. I; Francisco SuArez, Tractatus de legibus ac Deo legislatore, Coimbra 1612, vols. I-X.

10 Philipp Melanchthon, Loci communes, in: Hans Engelland (ed.), Melanchthons Werke, vol. II/1-2, Gütersloh 1952. For works by Lutheran lawyers see Merio ScatTola, Naturrecht vor dem Naturrecht. Zur Geschichte vom ius naturae im 16. Jahrhundert, Tübingen 1999.

11 P. Melancht hon, Loci, in: H. Engelland (ed.), Werke, II/1, p. 31; Hugo Grotius, De iure belli ac pacis libri tres (subsequentlye IBP) (1625), ed. P. C. Molhuysen, Leiden 1919, I/1, § 10.

12 Even Kant defines natural law as ,a priori“ but „durch jedes Menschen Vernunft erkennbare Recht". See Immanuel Kant, Metaphysik der Sitten, A/B 139 (Wilhelm Weischedel, Werke in zwölf Bänden, Frankfurt am Main 1978, vol. VIII, p. 412).

13 P. Melanchthon, Philosophiae moralis epitomes, in: Corpus reformatorum, Halle 1848, vol. 16, pp. 21-165. See Karl Anton Martini, De lege naturali exercitationes sex, Wien 1776, § 106; M. Scattola, Naturrecht, p. 84. 
natural law as laws which operate in nature without human interference. Humans were not supposed to interfere with the divine order of creation in any way. Dan Edelstein correctly points out that we should not suppose that authors writing about laws of nature before Newton would have implied an analogy with the laws of nature operating on their own. ${ }^{14}$ Their sources may have been Stoic philosophy and Roman law, as Dan Edelstein argues. Based on what I have read, Christian natural law thinkers knew such a conception from Plato's dialogues Timaeus and Phaedrus, where he also included the notion of natural law as leges caelestae. ${ }^{15}$ This conception was rejected by the Jesuit Francisco Suarez because it was at odds with the freedom of the will, and this Catholic conception of natural law finally prevailed. ${ }^{16}$ The idea of divine voice and passive corrupted humans did not disappear; it was defended by the French reformed theologian Pierre Poiret and later by Catholic theologians, enemies of secular natural law. ${ }^{17}$ However, theorists of secular natural law of both denominations sided with the notion of natural law discerned by human reason.

Another element that was needed was the notion of inalienable goods, which had been introduced by Grotius. ${ }^{18}$ But he did not connect it with any inalienable rights that would entitle humans to actively defend their rights in the civil state. This notion of inalienable goods, then, had a life of its own. We encounter it in Pufendorf ${ }^{19}$ and in John Locke but never coupled with active rights. ${ }^{20}$ It stands at the beginning of the idea of the enumeration of goods that should be protected by inalienable rights.

The last step in the formulation of human rights was to equip men with empowerments to defend these goods. This was done by the logician Christian Wolff, who started from Pufendorf's notion of universal human obligations, from which he logically derived universal human rights. ${ }^{21}$ In his view, if humans have obligations, then they also need rights to protect their ability to discharge their duties.

14 D. Edelstein, On the Spirit, pp. 115-117.

15 F. Suarez, De legibus, I, 3, § 4-5.

16 Iвidem.

17 See K. A. Martini, De lege, $\$ 106$.

18 H. Grotius, IBP, II, 17, § 2.

19 Samuel Pufendorf, De jure naturae et gentium (subsequently JNG) (1672), ed. Frank BöHLIG, Berlin 1998, III/1, § 1 .

20 John Locke, Two Treatises of Government, in: Ian Shapiro (ed.), John Locke, Two Treatises of Government and A Letter Concerning Toleration, New Haven 2003, p. 154 (II, § 123).

21 Christian WolfF, Jus naturae, Halle 1740 , chapter 1 „De obligatione et jure hominum universali in genere“, § 1-168; IDEM, Institutiones iuris naturae, Halle 1750, § 68-102. See Ivo Cerman, "Universal Human Rights" and Social Compact in Christian Wolf, Das Achtzehnte Jahrhundert und Österreich 31, 2016, pp. 124-146. 
What is important, furthermore, is the logical sequence of the predicates he uses. Wolff created equal, universal human rights. He put equality in the first place, because otherwise liberty and other rights would not pertain to all beings in the same manner. ${ }^{22}$ Liberties would have been merely privileges. Having equal rights implied the existence of a legal system which would have to be logically construed. That meant that for him there would be no logical contradictions. However, Wolff was able to construe such a logical web of inferences only at the level of interpersonal relations, not within the relation of individual citizens to public power.

This logical structure was, in my view, more important for the "birth of human rights“ than the claim that universal human rights were inherent in human nature. The argument of „innateness“ was just a metaphor, which misled many legal theorists into accusing early modern thinkers of a "naturalistic fallacy“. Norms - even a catalogue of human rights - cannot be "derived“ from facts, but they can be created as a response to facts. ${ }^{23}$ Besides, the notion of natural law also implies that we give up a belief in supernatural capacities, and this implication is still valid.

By 1748 natural law theorists had formulated the idea of equal universal human rights for individuals. It was the result of a longer development which included reducing the notion of law to human-related law, the victory of the concept of man as a reasonable creature, the identification of inalienable properties, the connection of these goods with active empowerments, and finally giving logical priority to equality, which led to systematic thinking about law. Even the idea of drafting a list of rights had been realized. Ephraim Gerhard drafted a list of rights in 1712, which responded to possible violations of the main precept "neminem laedere, suum cuique tribuere“ ${ }^{24} \mathrm{~A}$ number of minor authors writing after 1754 (the year of Wolff's death) drafted further lists of rights even before the American Revolution. The German legal historian Diethelm Klippel believes that these later German natural law thinkers managed to create a kind of preservation regime by either providing more detailed catalogues of human rights (Meier), which later merged together with the idea of freedom (Bahrdt, Heydenreich, Schaumann), or by elaborating the heritage of the passionate natural law inspired by Spinoza, which then resulted in economic theories of Justi and the German physiocrats (Schlettwein). ${ }^{25}$

22 See Hanns Martin Bachmann, Die naturrechtliche Staatslebre Christian Wolfs, Berlin 1977, pp. 101-102.

23 The core of David Hume's, naturalistic fallacy", as I understand it, was that it is fallacious to say that we „derive" norms from facts, since, derive" is a verb referring to logical operations. However, the lawgiver may certainly respond to facts by creating norms. We may respond to a murder by issuing a law prohibiting murders, but not by deriving a law that would make murders easier. „Naturalistic fallacy" in Hans Kelsen referred to the application of created norms to facts that we are judging. See Ivo Cerman, Přrrozenopráuni omyl podle Hanse Kelsena, Právník 158, 2019, pp. 837-851. Ephraim Gerhard, Delineatio iuris naturalis, Jena 1712, pp. 40-46, 101-196. 
However, we should add that all failed to create a logical system of law that would include even the sovereign (i.e. the legislator). The simple logic of deriving norms from one supreme premise was not able to accomplish that. Economic and "passionate" theories provided no solution to the logical problem of law.

\section{France and Natural Law(s)}

The trouble is that France and North America were, I would say, both exceptions, lying outside the borders of the European natural law area, where this development occurred. The core area of natural law were countries in which secular natural law was institutionalized and established as an academic discipline. These were mainly the Netherlands, Protestant Germany, Sweden, Switzerland, Scotland (not England) and later the Catholic Habsburg Monarchy, together with the Catholic parts of Germany. Russia introduced chairs of natural law twice, but after the Napoleonic Wars it prohibited natural law as a revolutionary ideology. Dan Edelstein's conclusions are correct for France and North America, but it was not there that the notion of universal human rights was formulated. For this reason, they cannot serve as a foundation for any generalizing statement about the irrelevance of natural law to human rights. Edelstein does acknowledge that „natural law did not just coexist alongside natural rights (..) it generated them" (p.103), but he also claims that the victory of the preservation regime was made possible by the declining influence of natural law theories around the mid- $18^{\text {th }}$ century (p. 5). This decline made room for a physiocratic economic theory which already blurred the borderline between the state of nature and civil state and therefore made it possible for people to carry their natural rights over into a civil society. This was, however, no solution; it was a metaphor which replaced the logical solution with a narrative.

France was an exception where the secular natural law was tacitly rejected; it was not taught at the universities. The first known chair of natural law was established at the Collège Royal in 1774 and given to Antoine Bouchaud. ${ }^{26}$ Diderot and Rousseau, who pondered on this subject, were private scholars, and their concepts were borrowed from authors from the field of natural law. ${ }^{27}$ As Dan Edelstein shows in previously unknown documents, even the lawyers who used natural law arguments to defend the parlements against Maupeou's revolution of 1771 drew on Christian Wolff. ${ }^{28}$ Legal scholars were less enthusiastic. In the early

26 Marie-Antoinette Lemasne-Desjoubert, La faculté du droit de Paris aux XVIIe et XVIIIe siècles, Paris 1966, p. 117; Lawrence BrockLiss, French Higher Education in the Seventeenth and Eighteenth Centuries, Oxford 1987, p. 279.

27 See Jacques Proust, Diderot et l'encyclopédie, Paris 1967², pp. 341-350, 405-448; Jean-Jacques Rousseau, Oeuvres complètes, vol. III, Paris 1964, p. 1443 (Robert Derathé's comment on the double social contract), Simone Goyard-Fabre, Grotius, Hugo, in: Raymond Trousson - Frédéric S. Eigeldinger (edd.), Dictionnaire de Jean-Jacues Rouseau, Paris 2006, pp. 393-394; EAdEm, Pufendorf, Samuel, in: ibidem, pp. 773-775. 
$18^{\text {th }}$ century, the Chancelier D'Aguesseau recommended Pufendorf's books to his son, ${ }^{29}$ but Dupont de Nemours in 1769 was already expressing doubts about the value of Pufendorf's conjectures $^{30}$, and Joseph-Michel-Antoine Servan in the 1780 s rejected the whole ,school of the north", in which he also included Grotius and Wolff. ${ }^{31}$

France chose its own way of achieving similar goals to those promised by systematic natural law in Central and Northern Europe. France skipped the stage of abstract reflections and focused on the cultivation of the domestic French law, which was elevated by the Edict of Saint Germain of 1679 to a scientific discipline with its own chairs at universities. $^{32}$ The second peculiarly French source was Roman law, which was believed to conceal within itself a deeper natural order. This is a development which Dan Edelstein grasps nicely. Jean Domat had a method of legal knowledge of his own, different from Pufendorf's. ${ }^{33}$ It appears that the French were ready to discern such hidden structures within existing laws and institutions rather than to apply general abstract formulas from abroad, as even $16^{\text {th }}$ century thinkers such as L'Hopital and Jean Bodin were ready to uncover such hidden orders within existing institutions. ${ }^{34}$

France had also its own way towards a systematization of law which was different from the secular natural law of Central Europe. ${ }^{35}$ The Code civil of 1804 did not draw on Central European natural law but on domestic traditions of droit coutumier and Roman

29 M.-A. Lemasne-Desjoubert, La faculté, p. 116.

30 Anthony Mergey, L'état des physiocrates: autorité et décentralisation, Aix-en-Provence 2010, p. 37.

31 John A. CAREY, Judicial Reform in France before the Revolution of 1789, Cambridge, MA, 1981, p. 114.

32 See Alfred de Curzon, L'enseignement du droit français dans les universités de France aux XVIIe et XVIIIe siècles, Paris 1920; M.-A. Lemasne-Desjoubert, La faculté, pp. 93-102; L. Brockliss, French Higher Education, pp. 277-279.

33 André-Jean Arnaud, Les origines doctrinales du Code civil français, Paris 1969, pp. 65-73, 124-129; J. A. Carey, Judicial reform, pp. 35-39.

34 J. A. CAREY, Judicial reform, pp. 36-40.

35 In terms of geography, it is interesting to note the case of Spain, which received mixed influences from both Central European natural law and France. There was a short-lived attempt to establish chairs of natural law between 1771-1804 (with Joaquín Marin y Mendoza as the first Spanish author) and, on the other hand, Ramon Lázaro de Dou i de Bassols who published, between 1800 and 1803, a huge work on Spanish laws modelled on Jean Domat's Les lois civiles. See Antonio Alvarez de Morales, La Ilustracón y la reforma de la universidad en la Espana del siglo XVIII, Madrid 1979², pp. 138-153; Salvador Rus Rufino - María Asunción Sánchez Manzano, 1772: La primera oposición universitaria al cátedra del derecho natural y de gentes, Revista de la Facultad del Derecho de la Universidad Complutense 80,1993, pp. 219-240; IDEM - EADEM, Historia de la cátedra del derecho natural y de gentes del los Reales Estudios de San Isidoro (1770-1794), Léon 1993; Francisco Tomás y Valiente, Génesis de la Constitución de 1812, Madrid 2011, p. 56. 
law, systematized by Jean Domat and Robert Joseph Pothier. ${ }^{36}$ At the heart of the French code was not the regulation of family relations, as in Central European codes, but of commercial relations. Even though France followed the trend towards systematic codification, it was a specifically French trend.

Rights talk and the preservation regime were actually developed in the physiocratic school, I would say, but even this was a peculiarly French development. This was a different school of thought which starts with Montesquieu, who renounced efforts to formulate general principles and devised a method which attributed a different type of government to each nation (peuple), based on their nature. In his method, humans were not supposed to impose logical frameworks on themselves, as in Wolff's method, but to adjust their laws to preexisting natural circumstances peculiar to the geographical place in which they lived. The physiocrats went one step further, because they actually described only preexisting physical natural laws to which humans had to adjust themselves. Even though they employed terminology similar to that of Central European natural law, it was a completely different school of thought, and the same words acquired different meanings. Theirs was a school of economic thought. In this regard, the divide between physiocrats and the field of natural law was even deeper than the divide between France and common law cultures.

\section{The Preservation regime in Physiocracy and Natural Law}

This fact diminishes somewhat the value of the physiocratic preservation regime as it did not provide any new logical solution to the clash of expanding individual rights and the objective legal order. On the other hand, the physiocrats could still be credited with encouraging the idea that individual liberty should be preserved within a state. This was their political and intellectual merit. We can already detect a similar political decision in the public discourse of seventeenth-century England before $1688,{ }^{37}$ and again in Rousseau's social contract, which advocates the preservation of "liberté civile“ as the ultimate goal of human societies. ${ }^{38}$ Liberty within a state was also advocated by the Göttingen school of passionate natural law, to which Johan Jakob Schmauss and Johann Christian Claproth belonged. ${ }^{39}$ They in turn inspired the Cameralist Johann Heinrich Gottlob von Justi, who transposed this idea into the realm of public economy, where it was supported

36 Jean-Etienne-Marie Portalis et alii, Discours préliminaires sur le projet de code civil, in: idem, Discours, rapports, et travaux inédits sur le Code civil, Paris 1844, pp. 1-63. See A.-J. Arnaud, Les origines, pp. 23-60, 121-214; Pierre Allorant - Philippe Tanchoux, Introduction historique au droit, Paris 2015, pp. 151-157.

37 See Caroline Robbins, The Eighteenth-Century Commonwealthman, Cambridge, MA, 1959, pp. 22-176.

39 D. Klippel, Politische Freiheit, p. 85; Frank Grunert, Das Recht der Natur als recht des Gefühls: Zur Naturrechtslehre von Johann Jacob Schmauss, Jahrbuch für Recht und Ethik 12, 2004, pp. 351-368. 
by means of economic arguments..$^{40} \mathrm{~A}$ similar transposition can be observed in the $1770 \mathrm{~s}$ among Italian thinkers of mixed economic and political interests such as Giuseppe Gorani and Carlantontio Pilati. ${ }^{41}$ Other authors writing before 1776, even German natural law thinkers, did not insist that the state should be construed in such a way that individual liberty should be protected. Even though Pufendorf and Wolff acknowledged that states in which the sovereign is limited by leges funamentales may exist, they did not say that such states were a better option. ${ }^{42}$ Nevertheless, the decision to preserve liberty in a state was not the same as the decision to preserve it in the form of a catalogue of human rights. We must stress again that „universal human rights“ are an instrument to preserve something, and not a good to be preserved. For this reason, we must look for thinkers who advocated the idea that liberty within a state should be protected by an enumeration of universal human rights in the plural.

In this regard, the physiocrats seem to have done just that. What they did was to follow Montesquieu in abandoning the idea of the social contract. Montesquieu replaced it with the idea of historical progress from the state of nature to the civil state. The physiocrats proceeded from the assumption that life in society is the original state of men and often tacitly made the transition from "état naturel" to "état politique" without explaining it. Some of them, as Anthony Mergey's splendid monograph informs us, believed that the natural order would subsequently urge people to enter in contracts with each other and thereby strengthen social bonds. However, they used the terminology of laws and rights to describe natural processes that occur even without human interference; they were not actually speaking about real law. They guaranteed the rights in the „état politique" by their belief in a kind of preestablished harmony between human acts and the natural order. They were sure that there were certain droits naturels de l' bomme, such as the need for alimentation, which are a part of natural order and which would make people act in a way that would be in harmony with the natural order.

If we look in their writings for an instrument which would guarantee that, we will see that both Quesnay and Mirabeau saw this guarantee in proper education. Quesnay believed that a progress in knowledge of the natural order, which would be diffused by education, would guarantee that even laws issued by humans would be more and more in compliance with the natural order. ${ }^{43}$ Mirabeau the Elder believed that people would have to study le code de la nature. ${ }^{44} \mathrm{~A}$ similar education about rights was proposed by $\mathrm{Le}$

40 Ere NоккаLA, From Natural Law to Political Economy, Wien 2019, pp. 66-70.

${ }^{41} \quad$ Franco Venturi (ed.), Riformatori lombardi del settecento, vols. I-II, Milano 19782; Wolfgang Rother - Johannes Roнвеск (ed.), Die Philosophie des 18. Jahrbunderts, vol. III. Italien, Basel 2011.

42 S. Pufendorf, JNG VI, 6, §§ 9-10; Ch. Wolff, Jus naturae (subsequently JN) VIII, §§ 66-79.

43 François Quesnay, Le droit naturel, Paris 1765, p. 33.

${ }^{44}$ Victor Riquetti marquis de Mirabeau, La science ou les droits et devoirs de l'homme par $L D H$, Lausanne 1774, pp. 152-53. 
Mercier de la Rivière. ${ }^{45}$ The reason why people are not already acting in accordance with natural laws and rights was explained by their belief that people had forgotten about them. A proper education would guarantee that this knowledge would be rescued from oblivion. This is the same mechanism that Condorcet later used in his Tableau historique, where the social contract is completely replaced by historical progress. ${ }^{46}$ After the recovery of the original morality, which occurred thanks to the invention of the printing press and the renewal of sciences during the Renaissance, people recovered the knowledge of their „droits naturels de l'homme" during the Enlightenment and this knowledge, secured by printed literature, ,raison publique and public education, seemed to be a better guarantee of morality than the obsolete social contract. ${ }^{47}$ Condorcet admitted that he was using physiocratic terms and logic but criticized their school for using, ,un langage obscure et dogmatique“. 48

This belief in a miraculous transformation of human nature was no legal solution. The doctrine of despotisme légal made further fundamental laws redundant, but the physiocrats still toyed with that idea, even before the death of Quesnay. ${ }^{49}$ In these projects, the main guarantee of peace was still the natural order which would somehow urge all parties to act in harmony. An unjust monarch would surely not manage to hold power for long, the physiocrats believed. The physiocratic monarch should not be resisted by his subjects, nor should he be accountable to anyone; ${ }^{50}$ republics were despised and mixed constitutions rejected. The liberty of the press was, however, encouraged. ${ }^{51}$ If we do not share their faith in the power of natural order, then the physiocratic solution may appear to be illusionary. It was only in 1789 that Le Mercier de la Rivière embraced the notion of moderated monarchy ${ }^{52}$ and joined the movement for a constitution in which droits naturels de l' homme played a new role. ${ }^{53}$

Unlike the physiocrats, the systematic natural law thinkers knew that constraining the sovereign by law would be a contradiction in terms. The sovereign held the ............

45 A. Mergey, L"état, p. 235.

46 Nicolas de Condorcet, Equisse d'un tableau historique des progrès de l'esprit humain, ed. by Yvon Belaval, Paris 1970, pp. 130-132 and 151. Condorcet claimed that people forgot their rights during the Middle Ages, and recovered them thanks to the invention of the printing press. For his relation to the physiocrats see Keith Michael Baker, Condorcet. From Natural Philosophy to Social Mathematics, Chicago - London 1975, pp. 18-21; Elisabeth Badinter - Robert Badinter, Condorcet. Un intellectuel en politique, Paris 1988, p. 47.

47 A. Mergey, L'état.

48 IвIDEM, p. 162.

49 A. Mergey, L'état, pp. 118-143, 168, 313-315.

50 IBidem, pp. 63-65.

51 IвIDEM, pp. 235-236.

52 Iвidem, pp. 336-343.

53 Iвidem, pp. 366-392. 
supreme power; he or she issued laws, and law means by definition that you bind someone else. A sovereign who would be bound by law would bind himself or herself, and therefore such laws would not be real law. ${ }^{54}$ The sovereign must be „humanis legibus solutus ". ${ }^{55}$ Could the laws be issued by a higher authority than the sovereign? If there was any higher authority commanding and judging the sovereign power, then sovereign power would rest with this higher authority. Conversely, if each citizen were equipped with the power to judge the sovereign, or raise arms against the sovereign, then the sovereign power would dissolve and people would fall back into the state of nature. ${ }^{56}$

The main ethical difficulty in the relation between the citizen and the sovereign was that imposing policies on the sovereign would mean imposing them on the public. The asymmetry of the relationship between the sovereign and the citizen made itself manifest in economic claims. ${ }^{57}$ By what right would an individual or a group impose policies fit for themselves on the rest of society? By what right would they require a larger share of the public welfare than others? Whereas relations between individuals could be regulated on the basis of the principle „suum cuique tribuere", the relation to public power could not be regulated in this way. Extending one's claims against others ad infinitum would also cause financial collapse.

\section{The Sovereign and the Citizen}

The natural law thinkers who wished to create a consistent legal system which would regulate even the relation to the sovereign solved the dilemma by removing the enforceable rights of the citizen against the sovereign. They reduced their reciprocal relationship solely to enforceable obligations of the citizen and enforceable rights of the sovereign towards the citizen. The citizen would have only non-enforceable claims upon the sovereign. Pufendorf claimed that the sovereign is bound to the citizen solely by duties of humanity, as man to man, ${ }^{58}$ Wolff argued that the sovereign is bound to perform only non-enforceable curae for his subjects, ${ }^{59}$ Martini insisted that the citizen might not enforce his rights against the sovereign ${ }^{60}$ and Kant concluded that

54 Thomas Hobbes, Elementa philosophica de cive, Amsterdam 1657, p. 8, § 7; S. Pufendorf,JNG, VII, $8, \S 2$.

55 S. Pufendorf, JNG VII, 6, § 3. See D. Kuippel, Politische Freiheit, pp. 54-56, 147-150.

56 I. Kant, Metaphysik der Sitten, A 177, B 207 (W. Weischedel, Werke, VIII, p. 440).

57 I. Cerman, Universal Human Rights, p. 143.

58 S. Pufendorf, JNG VII, $8, \S 2$,ex communi bumanitatis lege“.

59 I. Cerman, Universal Human rights, p. 142.

60 Karl Anton Martini, Lebrbegriff des Natur-, Staats- und Völkerrechts, Wien 1783, part II, §§ 379-380. See Ivo Cerman, Lidská práva v rakouském osvicenství. Wolf, Martini a Windischgrätz, Český časopis historický 111, 2015, pp. 300-334, here p. 326. 
„the sovereign in a state has only rights and no enforceable duties in relation to the subject. " ${ }^{11}$ Even if Pufendorf admitted that the monarch in a limited monarchy may be limited by leges fundamentales, he could not think of a logical solution to the dilemma of who would judge the sovereign. ${ }^{62}$ Wolff concluded that a ruler's violation of the leges fundamentales would have to be solved either by a friendly disputation, by a treaty, or be judged by external arbiters. ${ }^{63}$ Wolff could speculate about the question because sovereign power in a limited monarchy rested with those who issued laws, not with the monarch. In an actual limited monarchy, such as Great Britain, the parliament issued laws limiting the monarch, but none in which it [i. e. the parliament] would limit itself as the legislative body ${ }^{64}$ The limited British monarchy provided a political solution, but not a logical legal solution. The Whigs merely shifted the dilemma to another level. The American Bill of Rights of 1789/1791 did impose some limits on Congress. ${ }^{65}$

If Pufendorf, and after him Wolff, admitted that the populus in a limited monarchy ${ }^{66}$ might resist the unjust ruler with arms, then it would be fair to say that armed resistance is not a peaceful instrument, and battlefield is no court of justice. Permitting armed resistance is the same as saying that in the case that the legal order breaks down, parties may take up arms. It is useless to stipulate such procedures in a law. What was needed was a logically coherent legal order that would also bind the monarch.

Such a solution could be provided in a critical public sphere which would have allowed unjust laws or unjust policies to be criticized and corrected peacefully. However, criticizing valid laws of one's own country was considered immoral in the $18^{\text {th }}$ century. Bitter experience of periods of freedom of the press in Sweden (1766-1774), Denmark (1770-1771/73) and in the Habsburg monarchy under Joseph II (1781-1790) even induced these countries to issue laws prohibiting criticism. The only form of critical response to the government which the natural law theorists allowed was submitting complaints and petitions to the sovereign. ${ }^{67}$ Even Kant did not go any further. ${ }^{68}$ It was only the generation of natural law theorists writing at the time of the French Revolution that

61 I. Kant, Metaphysik der Sitten, A 174/B204 (W. Weischedel, Werke VIII, p. 438).

62 The English impeachment was not considered by natural law theorists, perhaps because it could not be directed against the monarch. In this respect, the US concept of impeachment was new. Ch. WolfF, JN VIII, § 822.

64 Gordon S. Wood, The Origins of the Bill of Rights, American Antiquarian Society 1991, pp. 255-274.

65 IBIDEM.

66 Ch. WolfF, JN VII, 6, § 9-10; JN VIII, § 1046-1047, 1054.

67 IвIDEм VIII, § 1051.

68 I. Kant, Metaphysik der Sitten, A 175/ B 205 (W.Weischedel, Werke, VIII, p. 438). 
began to ask for the right to criticize even the sovereign in public discussion. ${ }^{69}$ Furthermore, natural law theorists could not yet conceive of supreme or constitutional courts that would enforce law against ministers or even the monarch. It was only $19^{\text {th }}$-century liberals who shifted their focus from abstract systems to particular institutions that guaranteed civil liberty within a state. They required liberty of the press, public schooling, representative parliaments, accountability of ministers, and some kind of supreme court judging the ministers because they believed that the establishment of these institutions would guarantee "civil rights“. ${ }^{70}$ The dilemma of who would judge the sovereign was solved by a cunning trick borrowed from Blackstone: while the monarch was supposed to be unaccountable as the notional lawgiver, his ministers (i. e. the government) had criminal responsibility for their policies. ${ }^{71}$

It was again only in the late $19^{\text {th }}$ century that Georg Jellinek and Hans Kelsen returned to the quest for coherent legal order and sought to find ex post facto legal justification for the institutions of the liberal state. ${ }^{72}$ It was, however, within a completely different institutional, legal and political context, which already included a critical public sphere. We should now consider whether it is not unfair to place the early modern systematic thinkers among representatives of the „abridgement regime“ just because they were trying to integrate rights within a logically consistent legal system, whereas every pamphleteer who merely put forward simple slogans would undeservedly be awarded a place among the supporters of the "preservation regime“. Besides, the physiocrats did not admit either armed resistance or the accountability of the ruler. ${ }^{73}$

\section{Rights between Citizens}

Let us now turn to rights between private citizens. At this level, the principle „neminem laedere, suum cuique tribuere" could apply. Almost all natural law thinkers acknowledged that these reciprocal rights of individuals should be respected even in the civil state after the social contract. It was only supposed that citizens under law should not use violence to defend themselves because the state would take care of their security and the courts

69 Karl Friedrich BAhrdt, System der moralischen Religion, Berlin 1787, pp. 224-258. See D. KLippel, Politische Freiheit, p. 123.

70 Ivo Cerman, Všeobecná práva státních občanũ v prosincové ústavee, Právník 156, 2017, Nr. 12, pp. 1097-1108.

71 IвIDEM, p. 1099.

72 See Georg Jellinek, System der subjektiven öffentlichen Rechte, Freiburg im Breisgau 1892; IDEM, Allgemeine Staatslehre, Berlin $1914^{3}$ (1. Auflage Berlin 1900), pp. 327-335, 409-427; Hans Kelsen, Hauptprobleme der Staatsrechtslehre, Tübingen 1911, pp. 567-573, 629-663.

73 A. Mergey, L'état, pp. 63-65. 
protecting their rights. Some of these thinkers, however, would express this conviction in terms of "permissions in law" rather than by providing a catalogue of rights. ${ }^{74}$

What are we speaking about at this level? Actually, we mean two different spheres. Firstly, we are speaking about reciprocal obligations between individuals, which result in rights against our fellow-citizens, and secondly about actions outside the reach of laws which give citizens their sphere of private freedom. This sphere could be, in Christian Wolff's natural law, derived from the lex naturae permissiva from which rights are inferred..$^{75}$ This sphere of explicitly formulated rights was combined with a broad sphere of acts that were permitted tacitly, simply by not being regulated by laws. Wolff admitted that human laws may leave untouched even acts which are naturally impermissible (quod naturaliter illicitum). ${ }^{76}$ This sphere of permissio legis was another source of rights. Wolff emphasized that the lex naturae permissiva, which was a part of the supreme natural law, was valid even after the social contract. ${ }^{77} \mathrm{He}$ also confirmed respect for this tacit permission and thereby provided quite a large sphere of personal freedom. He did not define this sphere by a list of rights but by insistence that laws must respect permissive law. Besides, he argued explicitly: "Jura, quae hominibus natura tribuit, per civitatem non extincta sunt, sed saltem exercentur per alios." ${ }^{78}$ The question is whether he should be ranked among the representatives of ,abridgment regime“ just because he used a different legal instrument.

The real question for early modern thinkers was, however, whether these permissions constituted a part of law. Grotius argued that „Permissio proprie non actio est legis, sed actionis negatio... " ${ }^{\text {"79 }}$ In other words, what is permitted lies outside the law. Apart from that, permissions were not compatible with the "command theory" which requires that law is a binding enforceable rule. Consequently, law was reduced to preceptive rules and prohibitive rules, as logical opposites. The same view was followed by Pufendorf. ${ }^{80}$ Gottfried Achenwall, who came after Wolff, returned to the opinion that permissions are not a part of law. ${ }^{81}$ Kant, who drew on Wolff, doubted whether lex permissiva is necessary because actions that do not pertain to our freedom are indifferent and do not

74 See B. Tierney, Liberty, pp. 308-317; I. Cerman, Universal Human Rights, p. 139; Joachim Hrusch Ka, Das deontologische Sechseck bei Gotffried Achenwall im Jahre 1767, Hamburg 1986. 
require any authorization by such a law. ${ }^{82}$ In his view, the broader range of actions for which we have Befugnis (authorization) but no Verbindlichkeit (obligation) belong to Billigkeit (equity) or ius latum and lie outside law. ${ }^{83}$ These thinkers sought to construe a coherent legal order and excluded permissions because they failed to comply with their conception of laws as binding obligations.

Now American legal historians, most notably John Philipp Reid, could argue that the common law culture was more liberal than systematic natural law. ${ }^{84}$ But common law was liberal only as long as it remained in the inchoate form of case law; as soon as English and American thinkers began to construct a coherent system, they stumbled against the same problems, and reached similar results. John Locke preserved rights only in the state of nature, as Dan Edelstein correctly maintains. ${ }^{85}$ In the manuscript Obligations of penal laws of 1676, Locke disclosed that he held all human laws to be penal laws, i. e. he implicitly excluded permissions from law. ${ }^{86}$ Blackstone was quite unsystematic because he repeated after Pufendorf that real law is ", rule of action dictated by a superior being " ${ }^{\text {" }}$, but at the same time maintained that real laws are cases, whereas laws issued by kings were only doing damage. ${ }^{88}$ The first conception reduced law to prescriptions and prohibitions; the second left some latitude for liberties because it was not a coherent system.

American thinkers were liberal in framing the US federal constitution, and in some legal cases, but when the first commentators in the early $19^{\text {th }}$ century tried to construe a system, they aimed to achieve similar conclusions to those of their European counterparts. David Hoffmann, in his groundbreaking lecture course at the University of Maryland, was faithfully following the structure of European natural law theories. He, too, explained to his students that natural rights are limited after the transition from primary society to civil government. ${ }^{89}$

82 I. Kant, Metaphysik der Sitten, A22/B22 (W. Weischedel, Werke VIII, p. 329).

83 I. Kant, Metaphysik der Sitten, A39/B39 (W. Weischedel, Werke VIII, p. 341).

84 John Philipp Reid, The Irrelevance of the Declaration, in: Hendrik Hartog (ed.), The Law in the American Revolution and the Revolution in the Law, New York 1981, pp. 46-92; IDEM, The Authority of Rights at the American Founding, in: Barry Alain SHAin (ed.), The Nature of Rights at the American Founding and Beyond, Charlottesville 2007, pp. 66-115; IDEM, Constitutional History of the American Revolution, vol. I. The Authority of Rights, Madison, WI, 1986, pp. 9-11, 87-95.

85 D. Edelstein, On the Spirit, pp. 50-55.

86 John Locke, Obligation of Penal Laws, in: Mark Goldie (ed.), John Locke, Political Essays, Cambridge 1997, pp. 235-237.

87 William Blackstone, Commentaries on the Laws of England, Oxford 1765, vol. I, p. 39, 43 (a reference to Pufendorf in connection with the law of nations), 53 (definition of municipal law). Івгдем, p. 10, 18, 63-80 (on leges non scriptae, 230-270 (on the King's prerogatives). 1821-1837, Clark (New Jersey) 2011, pp. 74-76. 


\section{Did natural law endorse slavery?}

Let me also add to this short comparison between European natural law and American case law a brief reflection about the question of slavery. Some German historians have charged natural law with supporting slavery. They noticed that natural law manuals usually contained a chapter on servitium / Knechtschaft, which usually provided a succinct account of the legal status of slaves but no moral rejection of slavery. ${ }^{90}$ What they failed to see is that natural law thinkers used the word but substituted a different meaning. Wolff stressed that servitium does not mean jus vitae ac necis (i.e. power over life and death), but only lifelong entitlement to the fruits of the slave's labor. ${ }^{91} \mathrm{He}$ also stipulated that the master has certain duties towards the slave, who is conversely protected by rights. His inferences inspired Joachim Potgiesser to defend the liberty of serfs as early as $1736 .{ }^{92}$ Besides, the great debate about Johann Georg Estor's injurious essay on serfdom induced natural law thinkers to defend the liberty of serfs in the 1730s and $1740 \mathrm{~s} .{ }^{93}$ The effort to systematize law on the basis of logical equality actually endorsed the abolition of serfdom in Central and Eastern Europe. The liberty of the former serfs was confirmed in civil codifications even before it was guaranteed in constitutions.

What is strange about the attitude of the French Enlightenment philosophers, at least in the way I see it, is not the fact that they expressed little interest in the destiny of slaves in distant colonies but that they expressed little interest in the condition of French peasants either. It is, however, argued that the abolition of servitude in royal domains in 1779 was motivated by a campaign led by Voltaire. ${ }^{44}$ Even though it seems that the guiding spirit of this campaign was actually the lawyer Christin, Voltaire was involved. ${ }^{95}$ It seems, however, that no other leading philosophes joined him.

English and American case law advocated liberties, but it also helped to obscure the legal status of slaves. Actually, the very existence of slavery was obscured, since English common law did not recognize slavery. It was not until Lord Mansfield's ruling in the

90 Diethelm KLIPpel, Politische Freiheit und Freiheitsrechte im deutschen Naturrecht des 18. Jahrhunderts, Paderborn 1976, pp. 57, 77, 128; H. M. Bachmann, Die naturrechtliche Staatslehre, pp. 202-206; Emanuel Stipperger, Freibeit und Institution bei Christian Wolf (1679-1754), Frankfurt am Main 1984, pp. 78-80; Klaus-Gert LutTer Beck, Staat und Gesellschaft bei Christian Thomasius und Christian Wolf, Stuttgart-Bad Cannstatt 2002, p. 180.

91 Ch. WolfF, JN VII, § 1087-1089; For further discussion of slavery see JNI, § 146; JNVII, § 1080; IJN, § 947.

92 Joachim Potgiesser, Commentarius iuris germanici de statu servorum, Lemgo 1736, p. 10.

93 Johann Leonard Hauschild, Opusculum historico-juridicum praesumtionem pro libertate naturali in causis rusticorum, Dresden 1748. See Lorenz SteIn, Innere Verwaltungslehre, vol. III/1, Stuttgart 1868, pp. 157-159.

94 André Castaldo - Yves Mausen, Introduction historique au droit, Paris 20134, p. 407.

95 See Thierry Bressan, Serfs et mainmortables en France au XVIIIe siècle. La fin d'un archaïsme seigneurial, Paris 2007, pp. 111-168. 
Somerset case of 1772 that this fact was firmly established. This decision was influenced by European natural law because Lord Mansfield was known to have molded common law to the systematic thinking of continental theorists. ${ }^{96}$ However, his ruling did not apply in North America. American judges could even use the non-existence of slavery in common law to defend so-called pure slavery, as Judge John Hall did in State v. Boon (1801). ${ }^{97}$ In this ruling, the Judge even justified his decision with reference to Montesquieu's doctrine of natural slavery.

The status of slaves varied even between the American colonies, and between member states of the union after 1776. It is worth noting that the gradual emancipation of slaves in Connecticut was supported by a similar shift in the meaning of "slavery“ which had occurred in European natural law. The term was redefined as an entitlement to the fruits of the slave's labor. ${ }^{98}$ The legal status of slaves in slaveholding states was obscured because efforts to codify US law failed. The courts in Southern states then sometimes used natural law arguments to help slaves, such as the North Carolina judge John Louis Taylor in his dissenting opinion in State v. Boon $(1801)^{99}$, and sometimes to strengthen slavery, as Judge Thomas Ruffin did in Lemmond v. Peoples (1848). ${ }^{100}$ Judge Green of Tennessee in Ford v. Ford (1846) even invoked „high-born nature“ and „rights inherent in man“ to defend the slave's claim to freedom. ${ }^{101}$ Natural law could be invoked to justify manumission in cases when there were no statutes to justify it, as Judge Ruffin ruled in Redding v. Findley (1858). ${ }^{102}$ Here, however, „natural-law arguments" denote only the application of natural-law terminology, not the application of any particular European theory. A systematic approach to law did not prevail in the USA. Systematic law would have at least made it clear what the status of slaves was. It would have rendered visible the fact that a significant percentage of allegedly free Americans were held in a legal status which was clearly violating the freedoms guaranteed by the Constitution. ${ }^{103}$

96 Gerald J. Postema, Bentham and the Common Law Tradition, Oxford 1986, pp. 34-35; Justin Buckley Dyer, Natural Law and the Antislavery Constitutional Tradition, Cambridge 2012, pp. 52-55.

Thomas D. Morris, Southern Slavery and the Law 1619-1860, Chapel Hill-London 1996, p. 50.

Comments by Reeve and Gould of the Litchfield school. See Ellen Holmes Pearson, Remaking Custom. Law and Identity in the Early American Republic, Charlottesville 2011, pp. 123-124.

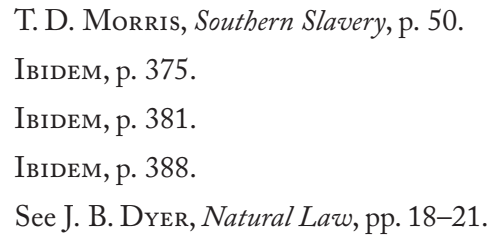




\section{Conclusion}

All this aims to show that human rights must be seen as a part of law, and that law must be continuously accommodated to changing social circumstances. Even if human rights are held to be immutable, they need a changing legal context to acquire power and meaning. Law is an instrument; it does not have to call for the abolition of institutions such as serfdom or slavery, but it can be used to regulate them. Even though the works of Diethelm Klippel, Franco Venturi, Anthony Mergey and now Dan Edelstein show convincingly that the political motivation for eighteenth-century "preservation regimes“ came from economic theories, legal theories should not be disregarded either. Human rights are an artificial instrument of law which is meaningless without its legal context, and this should also be reflected in the historiography of human rights. 
Ivo Cerman

\section{On the Rights without Natural Law}

\section{Abstract}

Whereas Dan Edelstein's interpretation may hold true for France, its general statements may mislead readers into disregarding the significance of systematic natural law for the formulation of human rights. The contemporary American historians of human rights also tend to attribute the main role to feelings, and not to legal theories. For this reason, the contribution first seeks to prove that systematic thinking of natural law theorists was necessary for the conception of the idea of „equal and universal human rights“. The argument goes on to prove that France was an anomaly, lying outside the core area of natural law (i.e. countries where natural law was institutionalized in university chairs). The preservation regime developed by the physiocrats was a part of their physicist way of thinking about human society, not a logical solution to the legal relationship between the citizen and public power. Even other libertarian thinkers in Germany and Italy were actually speaking about economics rather than about real law. The physiocrats found the solution in proper education, not in law. The article surveys how natural law thinkers were trying to solve the dilemma implicit in the relation between individual citizen and public power, and how they regulated the relations between individual citizens. While the relation to public power required logical legal thinkers to make sovereign power unaccountable to anyone, the reciprocal rights at the level of individuals were usually recognized, but sometimes in the form of general legal permissions and not in the form of a list of rights. The British-American tradition of common law often seems to be more liberal, but its chaotic nature actually helped to conceal the existence of slavery and the disadvantaged status of slaves.

KEY WORDS:

natural law; human rights; Samuel Pufendorf; Christian Wolff; physiocrats 